\title{
Current Situation of GNSS Networks in Romania
}

\author{
Alexandru-Iulian ILIESCU ${ }^{*}$, Tiberiu RUS ${ }^{2}$, Valentin DANCIU², Constantin MOLDOVEANU², Andrei ILIE ${ }^{2}$ \\ ${ }^{1}$ Department of Mathematics, Physics and Land Measurement, University of Agronomic Sciences and \\ Veterinary Medicine of Bucharest, Romania \\ ${ }^{2}$ Technical University of Civil Engineering, Faculty of Geodesy, Research Centre for Space Geodesy, \\ Photogrammetry, Remote Sensing and GIS (GEOS) \\ *corresponding author, e-mail: pfailiescu@yahoo.com
}

BulletinUASVM Horticulture 76(2) / 2019

Print ISSN 1843-5254, Electronic ISSN 1843-5394

DOI:10.15835/buasvmcn-hort: 2019.0040

\begin{abstract}
Nowadays, the need for a more precise positioning is a very high, therefore very demanding one, and this is one of the reasons why very large research funding is allocated in satellite technology, the second reason being global geopolitics situation. New satellite constellations are being developed existing satellites that have completed their mission are being replaced with satellites that incorporate technology far superior to their predecessors. Currently we have four constellations with global coverage, NAVSTAR-GPS and Glonass, Galileo and Compass. With the development of these global satellite systems, it is also necessary to develop the user segment, so this requires terrestrial reference stations to be updated to recognize the new signals from them. The article presents the situation of the global satellite systems and the situation of the permanent reference networks in Romania, which are developed by state or private companies.
\end{abstract}

Keywords: permanent stations, RTK, satellite constellations

\section{Introduction}

If we refer to the situation of the national reference network we can say that the first degree network consists of 74 GNSS stations, which are part of the national network ROMPOS.
The situation of the satellite constellations is one in continuous change, whether we are talking about new satellite constellations that are emerging orbiting satellites, or we are talking about old satellite constellations that are in a pro-

Table 1. National reference stations

\begin{tabular}{lcccc}
\hline \multicolumn{1}{c}{$\begin{array}{c}\text { Type of } \\
\text { network }\end{array}$} & $\begin{array}{c}\text { Precision of the } \\
\text { network level }\end{array}$ & Application & $\begin{array}{c}\text { Precision of } \\
\text { the network }\end{array}$ & $\begin{array}{c}\text { Network } \\
\text { information }\end{array}$ \\
\hline $\begin{array}{l}\text { National } \\
\text { Geodetic } \\
\text { network }\end{array}$ & $\begin{array}{c}\text { A level (CORS } \\
\text { stations) }\end{array}$ & $\begin{array}{c}\text { Regional and local } \\
\text { Feodynamics, deformation } \\
\text { projects, topographic } \\
\text { engineering }\end{array}$ & $+/-1.0 \mathrm{~cm}$ & $\begin{array}{c}74 \text { GNSS stations }- \\
\text { ROMPOS stations }\end{array}$ \\
\hline Second grade & B level & Topographic engineering & $+/-2.0 \mathrm{~cm}$ & 303 points \\
\hline Third grade & C level & $\begin{array}{c}\text { Topographic engineering and } \\
\text { cadastre }\end{array}$ & $+/-3 \mathrm{~cm}$ & 1171 points \\
\hline Fourth grade & D level & $\begin{array}{c}\text { Topographic engineering, } \\
\text { cadastre, GIS application }\end{array}$ & $+/-5 \mathrm{~cm}$ & 957 points \\
\hline
\end{tabular}


Table 2. Current situation of satellite constellations (Iliescu, 2019)

\begin{tabular}{cccccc}
\hline Satellite system & $\begin{array}{c}\text { Year of first } \\
\text { satellite launch }\end{array}$ & $\begin{array}{c}\text { No. of satellite/no. } \\
\text { of satellite proposed }\end{array}$ & Orbital & Band & $\begin{array}{c}\text { Level of } \\
\text { covering }\end{array}$ \\
\hline NavStar-GPS & 1978 & $31 / 32$ & 6 orbital plane & L1, L2, L5 & Global \\
\hline Glonass & 1982 & 24 & 3 orbital plane & L1,L2,L30C & Global \\
\hline Galileo & 2011 & $26 / 30$ & 3 orbital plane & & Global \\
\hline Compass & 2011 & $25 / 35$ & 6 orbital plane & $\begin{array}{c}\text { E1, E2, E5B } \\
\text { and E6 }\end{array}$ & Global \\
\hline QZSS & 2010 & $4 / 4$ & $\begin{array}{c}\text { orbital plane } \\
-45 \text { degrees }\end{array}$ & $\begin{array}{c}\text { L1, L2C, } \\
\text { L5,E6 }\end{array}$ & Regional \\
\hline IRNSS & 2013 & $7 / 7$ & Geostationary & L5, S & Regional \\
\hline
\end{tabular}

gram to replace the old satellites with a new generation of satellites, more efficient (Rus, 2012; Iliescu, 2019).

\section{Materials and methods}

In the lastyears in Romania several networks of permanent stations have been developed. Several reasons were the basis for this development, one of the most important being the increased demand for the provision of RTK products for users working especially in the field of cadastral and engineering topography, another reason being that some suppliers of GNSS equipment wanted to offer clients a private service or some entrepreneurs who have found an opportunity to develop a unit alternative service to the national network, which has many minuses in recent years (Farcaș et al., 2016; Sălăgean et al., 2019).

Permanent stations position is known and they transmit to users, real-time corrections over the internet, using mobile networks. Positions determined by GNSS are expressed in different Coordinate Reference Systems (CRS) or data as ITRS (International Terrestrial Reference System), ETRS89 (European Terrestrial Reference System 1989), WGS84 etc. For daily applications coordinates expressed in such reference systems can be transformed in local data, as S42 (Krasovski ellipsoid 1940) in Romania (Moscovici et al., 2019; Păunescu et al., 2017).

Below are presented the most developed and known networks in Romania, that provide corrections to GNSS rover in the field.
1. ROMPOS CORS Network contains a total of 74 permanent stations in Romania, distributed over an area of $2375000 \mathrm{~km}^{2}$. Stations are integrated in the EUPOS system, 5 stations are integrated in EUREF-EPN (European Reference Frame - European Permanent Network): BUCU (Bucharest), BACA (Bacău), BAIA (Baia Mare), COST (Constanţa) and DEVA (Deva). The average distance between the stations is $70 \mathrm{~km}$. Network is managed by CNC (National Centre of Cartography). ROMPOS is developed with Leica equipment, mounted only on public buildings (Șuba et al., 2019).

Rompos provide „network” products (generated using the principles of calculating differential corrections based on the network of permanent GNSS stations: VRS (Virtual Reference Station), FKP (Flachen Korrektur Parameter, MAX - Master Auxiliary Concept), "nearest" products (single base) - (generated using the principles of calculating differential corrections based on a single permanent GNSS station) and RINEX products (at 30 seconds, but with a written request for a period, they can provide measurements at 1 second.

Starting with 2019, the network has 9 new reference stations that receive signals from the European satellite constellation Galileo.

2. GNSSPos GNSS network consists of 35 reference stations located all over Romania. It is a relatively new network, which offers an alternative solution to the positioning services. There are more permanent stations next to Romania, situated in Bulgaria, Serbia, Macedonia and Moldova. Offers 


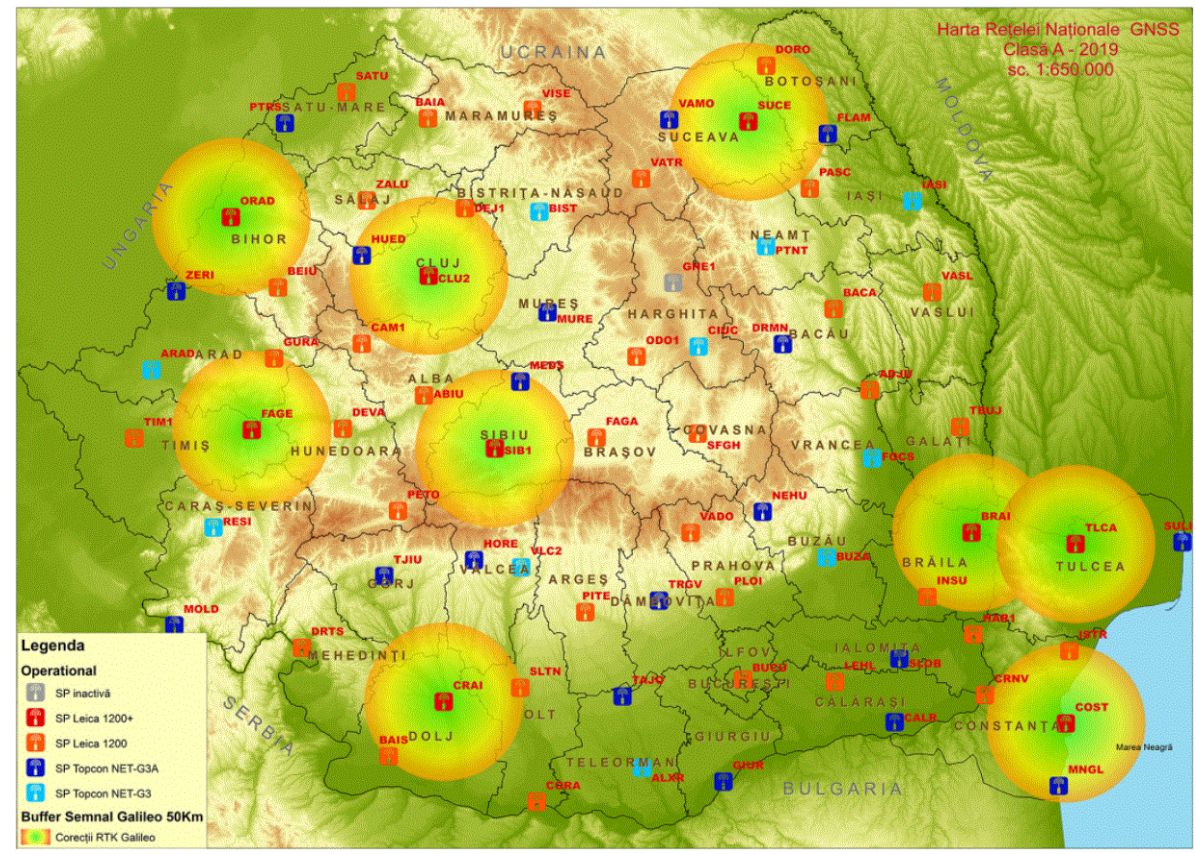

Figure 1. Permanent Galileo GNSS stations of the Rompos network (rompos.ro, 2019)

\begin{tabular}{|c|c|c|c|c|c|c|c|c|c|c|c|c|}
\hline \begin{tabular}{|l} 
RT Product nome \\
\end{tabular} & RT Product type & Cells/Sites/Rov... & Message Type & Connection Settings & Nttip Mount point & Check max di... & RTCM Version & Coord Rate & Re-checki... & Max dist... & lono \& Geomet.. & Re-check nearest si... \\
\hline F RO_MAX 3.1 & Automatic cells & . & MAX RTCM 3x (Eitended, 1015, 1016) & ROMPOS-Proxy:2101 & ROMAXX.1.1 & on & $3 x$ & $10 \mathrm{~s}$ & 1000 & 100 & 5s & On \\
\hline \% RO_VRS_.3.1 & Automatic cells & - & Virtual RS RTCM 3x (Ettended) & ROMPOS-Proxy:2101 & RO_VRS 3.1 & on & $3 x$ & 10s & 1000 & 100 & . & on \\
\hline Y. RO_imaX_3.1 & Automatic cells & - & i-MAX RTCM 3x (Eitended) & ROMPOS-Proxy:2101 & RO_MAX 3.1 & on & $3 x$ & 10s & 200 & 100 & - & On \\
\hline y. Nearest_3.1 & Nearest site & 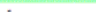 & RTCM 3.x (Ettended) & ROMPOS-Proxy:2101 & Nearest_3.1 & On & $3 x$ & 55 & 200 & 50 & 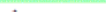 & On \\
\hline 4.4 Nearest_2.3 & Nearest site & - & RTCM 2.x (Type 1,2,18,19) & ROMPOS-Proxy:2101 & Nearest_2.3 & on & 2.3 & . & 200 & 50 & . & On \\
\hline Yy RO_FKP_3.1 & Automatic cells & & FKP RTCM 3.x (Extended, 1034, 1035) & ROMPOS-Proxy_2101 & RO_FKP 3.1 & on & $3 x$ & 5s & & 100 & . & On \\
\hline I. RO RIMAX 2.3 & Automatic cells & . & i-MAX RTCM 2x (Type 1,2,18, 19) & ROMPOS-Proxy:2101 & RO__imax 2.3 & On & 2.3 & . & 1000 & 100 & . & on \\
\hline S ROFKP 2.3 & Automatic cells & . & FKP RTCM 2x (Type 18, 19) & ROMPOS-Proxy:2101 & RO FKP 2.3 & on & 2.3 & . & 200 & 100 & . & on \\
\hline
\end{tabular}

Figure 2. Rompos network products

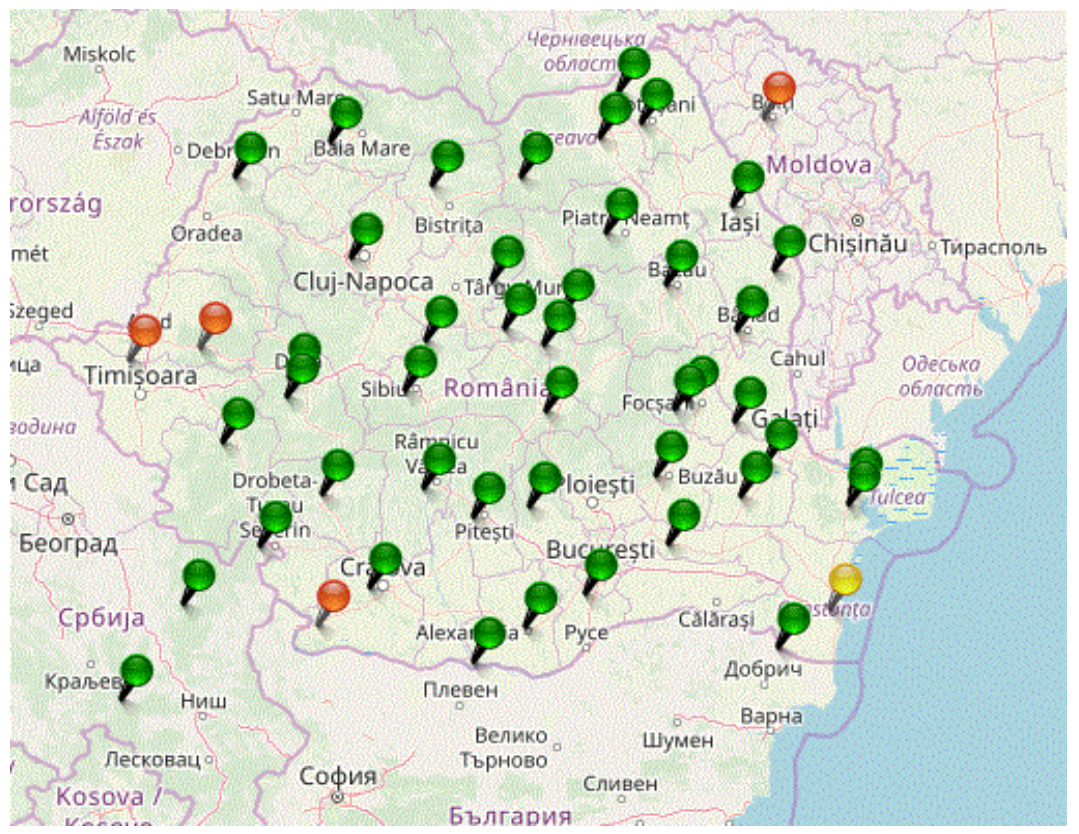

Figure 3. GNSSPOS CORS network in Romania (gnsspos.ro, 2019) 
network products (RTK) and RINEX products, by paying an annual subscription. It contains Trimble receivers (Cristea and Puia, 2016).

Most of the permanent stations are mounted at private users on buildings.

3. Trimble VRS GNSS network. Trimble Company realized in USA and Europe, GNSS services based on GNSS permanent station networks. Trimble services are known under the name 'Trimble VRS Now' due to the VRS (Virtual Reference Station) concept implemented for the first time by this company (Rus, 2012).

From 2012, 'Trimble VRS Now' services are available in Romania. The network contains 10 GNSS stations you can access the service by paying an annual subscription, offers RTK network solutions.

4. Leica TGREF GNSS network is owned and administered by SC Top Geocart SRL. Consists of 7 stations: TGBV - Brașov, TGGT - Odorheiu Secuiesc, TGRT - Botoșani, TGWA - Suceava, TGGC - Campina, TGTS - Moinești, TOPG București (topgeocart.ro, 2019). It offers RTK corrections and RINEX products (for free). RTK service transmits corrections in Leica proprietary format.

5. TopoCadVest GNSS network is a private network of 29 permanent GNSS stations, 4 are located in the territory of Bulgaria. Soon there will be 9 more permanent stations. The network is equipped with Hi-Target receivers. It offers RTK corrections and RINEX products. At this point is a free service.

6. I.N.F.P. GNSS network is administered by National Institute of Earth Physics, it is developed especially in the eastern part of Romania for monitoring crustal movements and tectonic plate. It consists of 29 GNSS stations, offering RINEX products data for static measurements (postprocessing) for free. Stations are mounted on the concrete pillars with a depth of 1 meter in the ground. Leica receivers are used for most of the stations. Some stations offer measurements at a frequency of $10 \mathrm{~Hz}$, the rest records at a frequency of $1 \mathrm{~Hz}$.

7. I.N.C.D. GeoEcoMar (National Institute of Research and Development for Geology and Marine Geoecology) developed the network through a

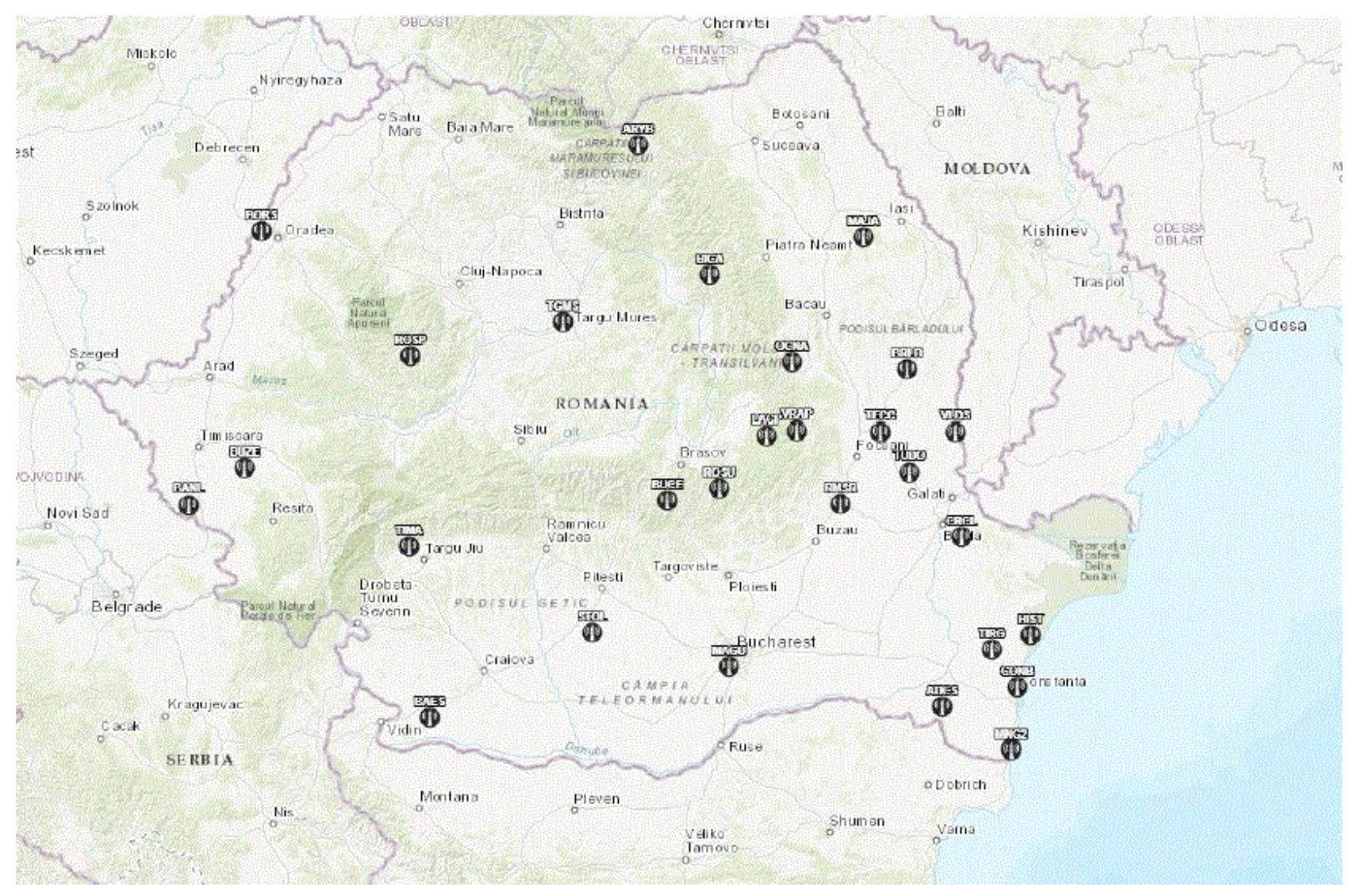

Figure 4. I.N.F.P. CORS network in Romania (infp.ro, 2019) 
European project being functional from 2013. It is composed of 13 GNSS stations located on the coastal area of Romania. The network is equipped with the GNSS Topcon receiver (reference station) model NET-G3A, GNSS antenna: Topcon, model CR-G5.

It is designed with the main purpose to allow the highlighting and then monitoring of the movements suffered by the different tectonic blocks that make up the terrestrial crust corresponding to the western continental edge of the Black Sea (geoecomar.ro, 2019). Currently the public does not have access to the network but with the development of the EUPOS project, maybe the data will be available.

\section{Results and discussion}

Permanent GNSS network stations in Romania are in continuous development, developed espe- cially by the equipment suppliers. Now there are 7 networks of permanent stations (3 managed by public institutions and 4 being private networks) that offer various products and are addressed to all types of users, but two networks of permanent stations offer restricted services for a certain segment of users.

The legislation allows the development of permanent networks by anyone who wants this, and how they want. It is not known how the network was implemented, how the network was processed, and if they are periodically monitored with network processing software. It is necessary to regulate permanent networks, through legislation that requires a standardization of the names, services offered, and how they are implemented. Most of the information that reaches the user is not clear and confuses, about the type of products offered.

\begin{tabular}{|c|c|c|c|c|c|c|c|c|c|c|}
\hline \multicolumn{11}{|c|}{ Ntrip streams: } \\
\hline Stream & L.. & Country & Lat & Long & Net & Format & Data type & Nmea & Phase info & 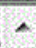 \\
\hline BA.A & & 0.00 & 1 & 0 & 0.00 & RTCM 3.2 & $1074(1), 1084[1], 1124[1], 1094(1), 1 \ldots$ & ZNet... & GPS GLO... & $\equiv$ \\
\hline$|A S| 3.1$ & & 0.00 & 0.00 & 1 & & $\mathrm{RTCM} 3$ & $1004(1), 1012(1), 1005 / 1007(10)$ & & & \\
\hline$B A \mid A, 20$ & & 0.00 & 0.00 & 1 & & RTCM23 & $3[10], 18[1], 19[1]$ & 1 & 2 & \\
\hline BUCU3.1 & & 0.00 & 0.00 & 1 & & $\mathrm{RTCM} 3$ & $1004(1), 1012(1), 1005 / 1007(10)$ & 0 & 2 & \\
\hline SATU3.1 & & 0.00 & 0.00 & 1 & & RTCM3 & $1004(1), 1012(1), 1005 / 1007(10)$ & 1 & 2 & \\
\hline PLOI & & 0.00 & 1 & 0 & 0.00 & RTCM 3.2 & $1074[1], 1084[1], 1124[1], 1094(1], 1 \ldots$ & ZNet... & GPS GLO... & \\
\hline ROSI & & 0.00 & 0.00 & 1 & & RTCM3 & $1004(1), 1012(1), 1005 / 1007(10)$ & 1 & 2 & \\
\hline BRAS & & 0.00 & 1 & 0 & 0.00 & RTCM 3.2 & $1074(1), 1084(1), 1124(1), 1094(1), 1 \ldots$ & ZNet... & GPS GLO... & \\
\hline$|\mathrm{AS|}|$ & & 0.00 & 1 & 0 & 0.00 & RTCM 3.2 & $1074(1), 1084[1], 1124(1), 1094(1), 1 \ldots$ & ZNet... & GPS GLO... & \\
\hline $\mathrm{BACA} 2.3$ & & 0.00 & 0.00 & 1 & & $\mathrm{RTCM} 2.3$ & $3[10), 18[1], 19(1)$ & 1 & 2 & \\
\hline TGMU3.1 & & 0.00 & 0.00 & 1 & & $\mathrm{RTCM} 3$ & $1004(1), 1012(1), 1005 / 1007(10)$ & 0 & 2 & - \\
\hline i.m. & & & & & & ing & & & 1 & \\
\hline
\end{tabular}

Figure 5. Example of providing confusing information

\section{Conclusions}

It is necessary to develop a methodology for processing the new networks implemented and monitoring them.

There are still problems in the continuous functioning of the networks, many of the stations being powered from the user's electricity grid, with no alternative source (a back-up power source).

A good part for the researchers is that some stations offer measurements at a frequency of 10 $\mathrm{Hz}$.

A proposal is an implementation of a common integrated system through which the user is redirected to the best station following an analysis by interpreting certain parameters (distance from de station, common satellites, data format and load of the server).

\section{References}

1. Cristea M, Puia MS (2016). National report Romanian GNSS permanent network.

2. Farcaș R, Sălăgean T, Palamariu M, Naș S, Ortelecan $M$ (2016). Considerations Regarding the Stability of Landmarks and Topographic Marks Placed in a Field of Salt Probes, RevCAD Journal of Geodesy and Cadastre, Alba Iulia, Romania, 45-50.

3. Iliescu A (2019). Contributii la utilizarea observatiilor GNSS in monitorizarea deplasarilor.

4. Moscovici AM, Păunescu V, Sălăgean T, Călin M, Iliescu A, Şuba EE, Grecea C, Manea R (2019). 3D Cadastre: A Smart 
Approach for Road Infrastructure, AgroLife Scientific Journal, ISSN 2285-5718, 8(1): 192-197.

5. Păunescu V, Călin M, Manea R, Moscovici A, Sălăgean T (2017). GIS in Active Monitoring of Green Spaces, Modern Technologies for the 3rd Millenium, Oradea, Romania, ISBN 978-88-87 729, 41(2): 73-78.

6. Rus T (2012). GNSS augmentation services in Romania.

7. Sălăgean T, Șuba EE, Pop ID, Matei F, Deak J (2019). Determining Stockpile Volumes Using Photogrammetric Methods, Scientific Papers. Series E. Land Reclamation, Earth Observation \& Surveying, Environmental Engineering, București, Romania, ISSN 2285-6064, 8: 114-119.
8. Şuba EE, Sălăgean T, Onose D, Pop ID, Matei F, Ortelecan M, Coroian I, Chiorean S (2019). Creating the Cartographic Database and Informatization of the Systematic Cadastre Works Process, Bulletin UASVM Cluj-Napoca, Romania, ISSN 1843-5254, Horticulture 76(1)

9. Geoecomar.ro - viewed at 2 September 2019

10. Gnsspos.ro - viewed at 2 September 2019

11. Infp.ro - viewed at 2 September 2019

12. Rompos.ro - viewed at 2 September 2019

13. Topgeocart.ro - viewed at 2 September 2019

14. Topocadvest.ro - viewed at 2 September 2019 